\title{
EKSTRAKSI DAN KARAKTERISASI SERAT SELULOSA DARI TANAMAN ECENG GONDOK (Eichornia crassipes)
}

\author{
Endang Kusumawati ${ }^{1, *}$, Haryadi ${ }^{1}$ \\ ${ }^{1}$ Jurusan Teknik Kimia, Politeknik Negeri Bandung, Jalan Gegerkalong Hilir Ciwaruga, Bandung Barat \\ *E-mail: endang.kusumawati@polban.ac.id
}

\begin{abstract}
ABSTRAK
Eceng gondok merupakan salah satu tumbuhan air mengapung yang pertumbuhannya cepat sehingga populasinya sulit untuk dikendalikan dan menyebabkan masalah lingkungan. Di sisi lain tumbuhan ini mengandung lignoselulosa yang terdiri dari $72,63 \%$ selulosa, $8 \%$ hemiselulosa dan $17 \%$ lignin. Kandungan selulosa yang tinggi menyebabkan batang tanaman ini berpotensi dijadikan bahan baku untuk pembuatan carbon nanodots (C-Dots). Tujuan dari penelitian ini yaitu mendapatkan jenis pelarut yang efektif untuk mengekstrak serat selulosa dari batang tanaman eceng gondok sehingga didapat konversi serat yang optimum. Agar eceng gondok bisa dijadikan bahan baku C-Dots, harus dilakukan pemisahan hemiselulosa dan ligninnya karena akan berpengaruh pada proses karbonisasi. Oleh karena itu, perlu dilakukan pretreatment untuk mendapatkan serat selulosa murni salah satunya yaitu ekstraksi. Proses ini dilakukan melalui dua tahap yaitu proses delignifikasi menggunakan $\mathrm{NaOH} 4 \%$ dan proses bleaching dengan memvariasikan jenis pelarut yaitu $\mathrm{NaClO}_{2}, \mathrm{H}_{2} \mathrm{O}_{2}$ dan $\mathrm{HCl}$ pada konsentrasi 3\%. Selulosa yang diperoleh dikarakterisasi menggunakan FTIR dan HPLC. Hasil analisis menunjukkan bahwa pelarut $\mathrm{NaOH} 4 \%$ dan $\mathrm{NaClO}_{2} 3 \%$ mempunyai berat selulosa yang lebih banyak dibandingkan kedua variasi pelarut lainnya. Hasil analisis FTIR tidak mendeteksi adanya gugus fungsi senyawa lignin pada selulosa, sedangkan hasil analisis HPLC diperoleh selulosa sebesar $77,6 \%$. Hal ini menunjukkan bahwa produk selulosa yang dihasilkan dari proses ekstraksi dengan pelarut tersebut efektif serta memiliki kemurnian yang tinggi.
\end{abstract}

Kata kunci: Ektraksi, delignifikasi, bleaching, eceng gondok.

\begin{abstract}
Eceng gondok is one of floating aquatic plant that grows fast so its population is difficult to control, this causes environmental problems. On the other hand, this plant species contains lignocellulose which consists of $72.63 \%$ cellulose, $8 \%$ hemicellulose and $17 \%$ lignin. The high cellulose content causes the stems of this plant to have the potential to be used as raw material for the manufacture of carbon nanodots (C-Dots). The purpose of this study was to obtain an effective type of solvent to extract cellulose fibers from the stems of the Eceng gondok plant in order to obtain optimum fiber conversion. Furthermore, to be used as raw material for C-Dots, the hemicellulose and lignin must be separated because it will affect the carbonization process. Therefore, it is necessary to do pretreatment to obtain pure cellulose fiber, one of which is extraction. This process is carried out in two stages, namely the delignification process using $4 \%$ $\mathrm{NaOH}$ and the bleaching process by varying several types of solvents such as $\mathrm{NaClO}_{2}, \mathrm{H}_{2} \mathrm{O}_{2}$ and $\mathrm{HCl}$ at concentration of $3 \% \mathrm{v} / \mathrm{v}$. The cellulose obtained was characterized using FTIR and HPLC. The results of analysis showed that the solvent $\mathrm{NaOH} 4 \%$ and $\mathrm{NaClO}_{2} 3 \%$ had more cellulose weight than the other two variations of solvents. The results of the FTIR analysis did not detect any functional groups of lignin compounds in cellulose, while the results of the HPLC analysis obtained $77.6 \%$ cellulose. This indicates that the cellulose product produced from the extraction process with the solvent is effective and has high purity.
\end{abstract}

Keywords: Extraction, delignification, bleaching, water hyacinth 


\section{PENDAHULUAN}

Eceng gondok (Eichhornia crassipes) adalah tanaman gulma terapung di wilayah perairan tenang. Eceng gondok mengandung protein lebih dari $11,5 \%$ dan mengandung selulosa yang lebih tinggi dari nonselulosanya seperti lignin, abu, lemak dan zat-zat lain. Ahmed (2012) menjelaskan bahwa komponen serat yang terdapat pada eceng gondok terdiri dari $72,63 \%$ selulosa, $8 \%$ hemiselulosa dan $17 \%$ lignin. Kandungan selulosa yang cukup tinggi pada eceng gondok tersebut dapat dimanfaatkan untuk berbagai keperluan diantaranya adalah sebagai bahan baku pembuatan carbon nanodots (C-Dots) yang dapat dilakukan dengan proses karbonisasi. Namun demikian terdapat kendala dalam pembuatan C-Dots berbahan baku eceng gondok, yaitu adanya kandungan hemiselulosa dan lignin yang akan berpengaruh dalam proses karbonisasi. Pada penelitian ini dilakukan pemurnian serat terhadap bahan baku eceng gondok agar didapatkan serat murni yang bebas dari hemiselulosa dan ligninnya.

Selanjutnya, Serat selulosa dapat diperoleh dengan cara mengekstrak selulosa dari batang tanaman eceng gondok menggunakan pelarut kimia agar selulosa keluar dari dinding sel (Perez, 2002). Proses pemurnian dapat dilakukan dengan cara ekstraksi yang meliputi proses delignifikasi menggunakan $\mathrm{NaOH} \quad 4 \%$ untuk memisahkan hemiselulosa dan lignin. Kemudian dilakukan proses bleaching menggunakan pelarut tertentu yang bertujuan untuk mendegradasi rantai lignin yang panjang menjadi rantairantai yang pendek sehingga lignin dapat larut pada saat pencucian dalam air atau alkali (Fengel,1995). Pada penelitian ini dilakukan variasi jenis pelarut yaitu hydrogen peroksida $\left(\mathrm{H}_{2} \mathrm{O}_{2}\right)$, sodium chlorite $\left(\mathrm{NaClO}_{2}\right)$ dan hydrocloric acid $(\mathrm{HCl})$ dengan konsentrasi yang seragam untuk mendapatkan pelarut yang efektif. Analisis kandungan serat selulosa yang telah dibuat ditentukan melalui uji karakterisasi menggunakan High Pressure Liquid Chromatogaphy (HPLC), sedangkan untuk memperoleh hasil lignin dan hemiselulosa yang terlarut dalam larutan alkali menggunakan Fourier Transform Infrared (FTIR) sehingga diperoleh gugus fungsi pada selulosa.

Tujuan penelitian ini adalah mendapatkan jenis pelarut yang efektif untuk mengekstraksi serat selulosa dari tanaman batang eceng gondok sehingga didapat konversi serat yang optimum.

\section{METODE}

Metode penelitian yang digunakan pada pembuatan serat selulosa murni merupakan metode eksperimen secara kimia yang terdiri dari dua tahap yang berkesinambungan yaitu proses delignifikasi menggunakan $\mathrm{NaOH}$ dan proses bleaching menggunakan variasi pelarut $\mathrm{NaClO}_{2}$, $\mathrm{H}_{2} \mathrm{O}_{2}$ dan $\mathrm{HCl}$, Selanjutnya, diuji karakteristik menggunakan FTIR dan HPLC.

Pada penelitian ini digunakan 40 gram batang eceng gondok untuk satu kali proses. Eceng gondok sebelum digunakan dicacah menjadi $1-3 \mathrm{~mm}$ menggunakan pisau dan blender dan selanjutnya dikeringkan didalam oven pada temperatur $105{ }^{\circ} \mathrm{C}$ selama 2 jam. Kemudian dilakukan proses ekstraksi untuk mendapatkan serat selulosa 
murni. Proses ekstraksi melibatkan dua tahap proses yaitu proses delignifikasi menggunakan $\mathrm{NaOH} 4 \%$ dengan lama pemanasan 2 jam pada temperatur $70^{\circ} \mathrm{C}$ sampai $80^{\circ} \mathrm{C}$. Sedangkan untuk proses bleaching menggunakan variasi pelarut $\mathrm{NaClO}_{2} 3 \%(\mathrm{w} / \mathrm{v}), \mathrm{H}_{2} \mathrm{O}_{2} 3 \%(\mathrm{w} / \mathrm{v})$ dan $\mathrm{HCl} 3 \% \quad(\mathrm{w} / \mathrm{v})$ dipanaskan pada temperatur $70^{\circ} \mathrm{C}$ sampai $80^{\circ} \mathrm{C}$ selama 3 jam. Selanjutnya disaring menggunakan corong buchner dan residu dikeringkan di dalam oven pada temperatur $105^{\circ} \mathrm{C}$ selama 2 jam. Proses ekstraksi dilakukan dua kali hingga warna selulosa menjadi putih.

Selanjutnya, selulosa kering dianalisis menggunakan FTIR untuk mengetahui gugus fungsi yang ada pada semua sampel. Filtrat proses ekstraksi dianalisis menggunakan HPLC untuk mengetahui jumlah lignin dan hemiselulosa yang terlarut dalam larutan alkali.

\section{HASIL DAN PEMBAHASAN}

\section{Ekstraksi Selulosa Menggunakan Larutan $\mathrm{NaOH} 4 \%$ dan $\mathrm{NaClO}_{2} 3 \%$}

Larutan alkali encer yang digunakan adalah larutan $\mathrm{NaOH} 4 \%$ untuk proses delignifikasi dan larutan $\mathrm{NaClO}_{2} 3 \%$ untuk proses bleaching. Proses ekstraksi selulosa akan menghasilkan lignin yang mengendap pada dasar larutan dan residu berupa selulosa yang lunak dan berwarna putih. $\mathrm{NaClO}_{2}$ merupakan zat pemutih oksidator yang berfungsi untuk mendegradasi dan menghilangkan zat penyebab warna coklat yang ditimbulkan oleh lignin (Rizky, 2012). Filtrat proses ekstraksi menggunakan larutan $\mathrm{NaOH} 4 \%$ dan $\mathrm{NaClO}_{2} \quad 3 \%$ diperlihatkan pada Gambar 1.

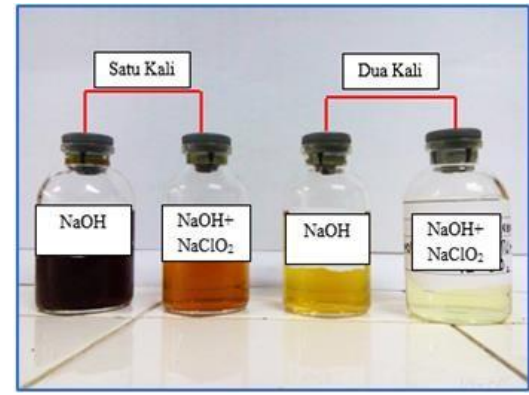

Gambar 1. Filtrat Ekstraksi dengan Larutan $\mathrm{NaOH} 4 \%$ dan $\mathrm{NaClO}_{2} 3 \%$

Dari Gambar 1 terlihat bahwa larutan $\mathrm{NaOH} 4 \%$ menjadi berwarna hitam yang menunjukkan adanya lignin yang telah terpisahkan dari selulosa dan terlarut dalam larutan $\mathrm{NaOH}$. Untuk memperoleh selulosa dengan kemurnian yang tinggi, maka proses ekstraksi dilakukan sebanyak dua kali. Setelah dilakukan proses sebanyak dua kali, maka warna filtrat semakin bening. Hal ini menunjukkan bahwa lignin yang terkandung dalam jumlah sedikit berhasil dipisahkan dari selulosanya. Adapun reaksi bleaching menggunakan larutan $\mathrm{NaClO}_{2} \quad 3 \%$ adalah sebagai berikut:

$$
\begin{aligned}
& 5 \mathrm{ClO}_{2}^{-}+4 \mathrm{H}^{+} \rightarrow 4 \mathrm{ClO}_{2}+\mathrm{Cl}^{-}+2 \mathrm{H}_{2} \mathrm{O} \\
& 4 \mathrm{ClO}_{2-}+2 \mathrm{H}^{+} \rightarrow 2 \mathrm{ClO}_{2}+\mathrm{Cl}^{-}+\mathrm{ClO}^{3-}+ \\
& \mathrm{H}_{2} \mathrm{O}
\end{aligned}
$$

Residu dikeringkan di dalam oven selama 1 jam pada temperatur $100^{\circ} \mathrm{C}$. Akhirnya Proses pengeringan menghasilkan selulosa berwarna putih yang menunjukkan bahwa diperolehnya selulosa dari proses ekstraksi yang disajikan pada Gambar 2.

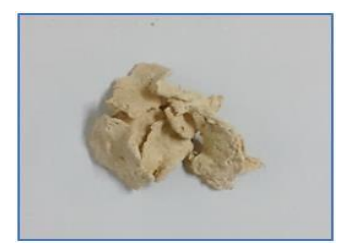

Gambar 2. Residu dengan Pelarut NaOH $4 \%$ dan $\mathrm{NaClO}_{2} 3 \%$ 
Gambar 2 memperlihatkan bahwa residu yang dihasilkan berwarna putih yang menunjukkan residu tersebut merupakan selulosa. Selulosa yang dihasilkan dari proses ekstraksi sebesar 23,05\% dari batang eceng gondok kering. Nilai persentase yang masih rendah disebabkan sebagian besar selulosa ada yang terlarut di dalam larutan ekstraksi.

Residu yang dihasilkan selanjutnya dianalisis menggunakan FTIR untuk mengetahui gugus fungsi yang terkandung didalamnya. Hasil Spektrum analisis FTIR dan gugus fungsi yang dihasilkan diperlihatkan pada Gambar 3 dan Tabel 1.

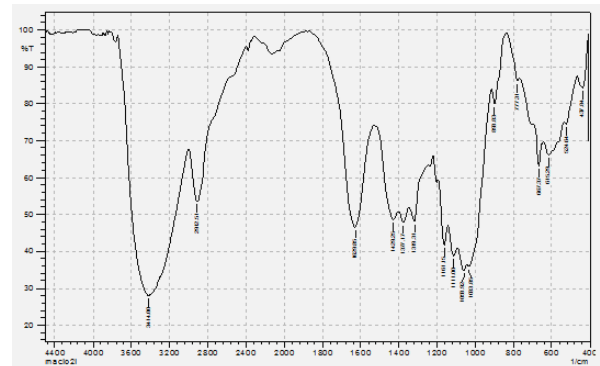

Gambar 3. Spektrum Analisis FTIR Residu dengan $\mathrm{NaOH} 4 \%$ dan $\mathrm{NaClO}_{2} 3 \%$

Tabel 1. Gugus Fungsi Residu Variasi Pelarut $\mathrm{NaOH} 4 \%$ dan $\mathrm{NaClO}_{2} \%$

\begin{tabular}{cccc}
$\begin{array}{c}\text { Daerah Puncak } \\
\left(\mathbf{c m}^{-1}\right)\end{array}$ & Ikatan & Tipe Senyawa & Intensitas \\
\hline 3414 & $\mathrm{O}-\mathrm{H}$ & Fenol (ikatan H) & Berubah-ubah \\
2912,51 & $\mathrm{C}-\mathrm{H}$ & Alkana & Kuat \\
1629,86 & $\mathrm{C}=\mathrm{C}$ & Alkena & Berubah-ubah \\
1319,31 & $\mathrm{NO}_{2}$ & Nitro & Kuat \\
$1068,92-1161,15$ & $\mathrm{C}-\mathrm{O}$ & Eter & Kuat \\
898,83 & $\mathrm{C}-\mathrm{H}$ & Cincin Aromatik & Kuat \\
\hline
\end{tabular}

Berdasarkan Tabel 1, didapatkan adanya puncak pada $2912,51 \mathrm{~cm}^{-1}$ dan $3414 \mathrm{~cm}^{-1}$ yang menunjukkan peregangan ikatan $\mathrm{C}-\mathrm{H}$ dan $\mathrm{O}-\mathrm{H}$. Puncak-puncak tersebut terjadi karena peregangan ikatan hidrogen dan pembengkokan dari grup hidroksil $(\mathrm{OH})$ pada struktur selulosa. Ikatan hidrogen tersebut terbentuk antara atom hidrogen dari suatu kelompok hidroksil dari suatu monomer glukosa dan atom oksigen dari gugus hidroksil monomer glukosa yang lain dalam rantai polimer paralel selulosa. Paulien (2010) menjelaskan bahwa ikatan hidrogen dapat menyebabkan terjadinya pembentukan serat selulosa.

\section{Ekstraksi Selulosa Menggunakan Larutan $\mathrm{NaOH} 4 \%$ dan $\mathrm{H}_{2} \mathrm{O}_{2} 3 \%$ \\ Filtrat proses ekstraksi menggunakan larutan $\mathrm{NaOH} 4 \%$ dan $\mathrm{H}_{2} \mathrm{O}_{2} 3 \%$ diperlihatkan pada Gambar 4.}

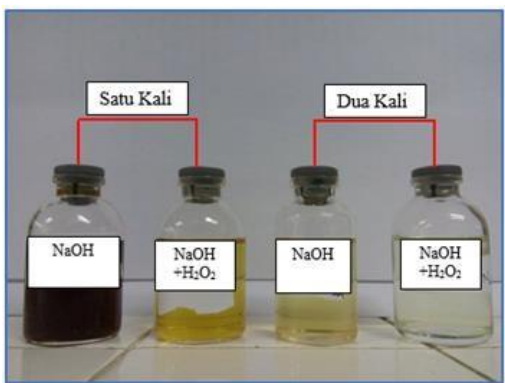

Gambar 4. Filtrat Ekstraksi dengan Larutan $\mathrm{NaOH} 4 \%$ dan $\mathrm{H}_{2} \mathrm{O}_{2} 3 \%$

Dari Gambar 4 terlihat bahwa larutan $\mathrm{NaOH} 4 \%$ menjadi berwarna hitam yang menunjukkan adanya lignin yang berhasil dipisahkan dari selulosa dan terlarut dalam larutan $\mathrm{NaOH}$. Taherzadeh (2007) menjelaskan bahwa struktur kimia lignin mengalami perubahan pada temperatur tinggi yang mengakibatkan struktur lignin terpecah menjadi partikel yang lebih kecil dan terlepas dari selulosa. Setelah dilakukan proses bleaching menggunakan $\mathrm{H}_{2} \mathrm{O}_{2}$ $3 \%$, warna filtrat berubah menjadi kuning keemasan yang menunjukkan sisa-sisa lignin yang terlarut di dalam larutan (Sinaga, 2008). Reaksi dekomposisi $\mathrm{H}_{2} \mathrm{O}_{2}$ ketika digunakan sebagai larutan bleaching (Fitho,2012) adalah:

$$
\begin{aligned}
& \mathrm{H}_{2} \mathrm{O}_{2(\mathrm{aq})} \leftarrow \rightarrow \mathrm{H}^{+}+\mathrm{HOO}^{-} \\
& \mathrm{H}_{2} \mathrm{O}_{2(\mathrm{aq})}+\mathrm{HOO}^{-} \rightarrow \mathrm{HO}^{-}+\mathrm{O}_{2}^{-}+\mathrm{H}_{2} \mathrm{O}_{(\mathrm{l})}
\end{aligned}
$$


Selanjutnya, residu yang diperoleh dikeringkan didalam oven selama 1 jam pada temperatur $100^{\circ} \mathrm{C}$. Proses pengeringan menghasilkan selulosa berwarna putih yang menunjukan bahwa diperolehnya selulosa dari proses ekstraksi yang disajikan pada Gambar 5.

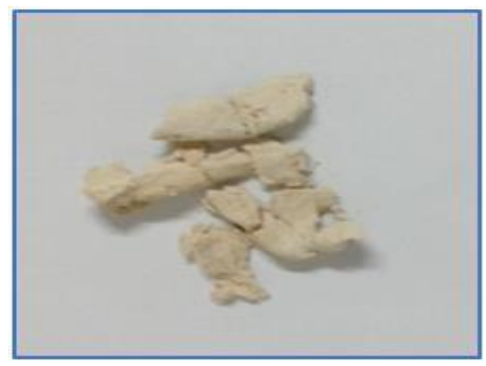

Gambar 5. Residu dengan Pelarut NaOH $4 \%$ dan $\mathrm{H}_{2} \mathrm{O}_{2} 3 \%$

Tekstur residu yang dihasilkan berbeda dengan tekstur residu pada variasi pelarut $\mathrm{NaOH} 4 \%$ dan $\mathrm{NaClO}_{2}$ $3 \%$. Residu yang dihasilkan memiliki tekstur halus. Hal ini menunjukkan bahwa lignin yang terkandung telah berhasil didegradasi. Selulosa yang dihasilkan dari proses ekstraksi sebesar $20,06 \%$ dari batang eceng gondok kering.

Selanjutnya, residu yang dihasilkan dianalisis menggunakan FTIR untuk mengetahui gugus fungsi yang terkandung. Hasil Spektrum analisis FTIR dan gugus fungsi yang dihasilkan diperlihatkan pada Gambar 6 dan Tabel 1.

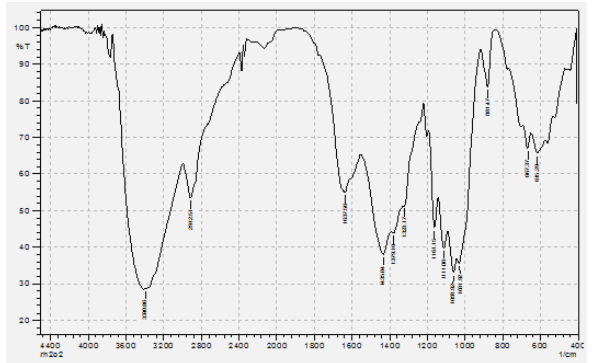

Gambar 6. Spektrum Analisis FTIR Residu Variasi $\mathrm{NaOH} 4 \%$ dan $\mathrm{H}_{2} \mathrm{O}_{2} 3 \%$

Tabel 2. Gugus Fungsi Residu Variasi Pelarut $\mathrm{NaOH} 4 \%$ dan $\mathrm{H}_{2} \mathrm{O}_{2} \%$

\begin{tabular}{cccc}
\hline $\begin{array}{c}\text { Daerah Puncak } \\
\left(\mathbf{c m}^{-1}\right)\end{array}$ & Ikatan & Tipe Senyawa & Intensitas \\
\hline 3390,66 & $\mathrm{O}-\mathrm{H}$ & Fenol & Berubah-ubah \\
2912,51 & $\mathrm{C}-\mathrm{H}$ & Alkana & Kuat \\
1637,56 & $\mathrm{C}=\mathrm{C}$ & Alkena & Berubah-ubah \\
1436,04 & $\mathrm{C}-\mathrm{O}-\mathrm{C}$ & Aril-Alkil-Eter & Kuat \\
1323,17 & $\mathrm{NO}_{2}$ & Nitro & Kuat \\
$1068,92-1161,15$ & $\mathrm{C}-\mathrm{O}$ & Eter & Kuat \\
881,47 & $\mathrm{C}-\mathrm{H}$ & Cincin Aromatik & Kuat \\
\hline
\end{tabular}

Berdasarkan Tabel 2, didapatkan adanya puncak pada $2912,51 \mathrm{~cm}^{-1}$ dan $3390,66 \mathrm{~cm}^{-1}$ yang menunjukkan peregangan ikatan C-H dan O-H. Selain itu hasil analisis menunjukkan adanya daerah puncak pada $1436,04 \mathrm{~cm}^{-1}$ yang menunjukkan adanya gugus fungsi $\mathrm{C}$ $\mathrm{O}-\mathrm{C}$ (aril-alkil-eter) yang termasuk ke dalam gugus fungsi polimer lignin. Hal ini menunjukan bahwa proses pretreatment yang dilakukan menggunakan variasi pelarut $\mathrm{NaOH} 4 \%$ dan $\mathrm{H}_{2} \mathrm{O}_{2} 3 \%$ tidak menghilangkan lignin yang terdapat pada selulosa.

\section{Ekstraksi Selulosa Menggunakan Larutan NaOH $4 \%$ dan HCl $3 \%$}

Proses ekstraksi selulosa dengan pelarut $\mathrm{NaOH} \quad 4 \%$ dan $\mathrm{HCl} 3 \%$ dilakukan dengan kondisi operasi yang sama dengan variasi pelarut sebelumnya. $\mathrm{HCl}$ berpotensi untuk memisahkan lignin dari selulosa yang terkandung karena memiliki reaktifitas yang tinggi. Filtrat proses ekstraksi menggunakan larutan $\mathrm{NaOH} 4 \%$ dan $\mathrm{HCl}$ 3\% disajikan pada Gambar 7. 


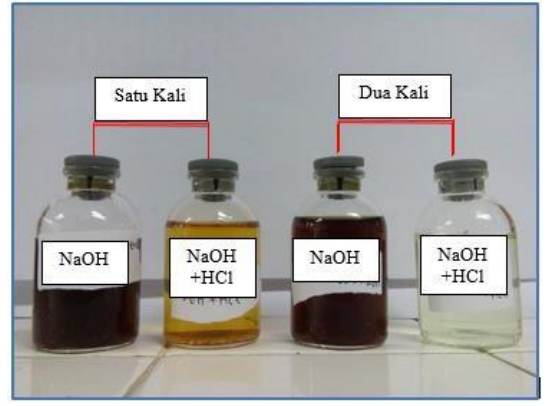

Gambar 7. Filtrat Ekstraksi dengan Larutan $\mathrm{NaOH} \mathrm{4 \%} \mathrm{dan} \mathrm{HCl} 3 \%$

Dari Gambar 7, terlihat bahwa larutan $\mathrm{NaOH} 4 \%$ menjadi berwarna hitam yang menunjukkan adanya lignin yang berhasil dipisahkan dari selulosa. Namun demikian, setelah dilakukan proses delignifikasi yang kedua, larutan $\mathrm{NaOH}$ tetap berwarna hitam. Hal ini menunjukkan bahwa proses bleaching menggunakan larutan $\mathrm{HCl} 3 \%$ tidak berhasil dilakukan. Hal ini kemungkinan disebabkan karena timbulnya $\mathrm{H}_{3} \mathrm{O}^{+}$dan $\mathrm{Cl}^{-}$dari dekomposisi $\mathrm{HCl}$ dalam air pada temperatur tinggi dengan reaksi sebagai berikut:

$\mathrm{HCl}+\mathrm{H}_{2} \mathrm{O} \rightarrow \mathrm{H}_{3} \mathrm{O}^{+}+\mathrm{Cl}^{-}$

Zat-zat ini berpotensi untuk memisahkan lignin, namun merusak selulosa yang dihasilkan (Paulien,2010). Kerusakan selulosa ditunjukkan dengan warna cokelat kehitaman pada residu dengan indikasi bahwa kandungan terbanyak pada residu merupakan lignin. Residu yang dihasilkan ditujukan pada Gambar 8.sebagai berikut:

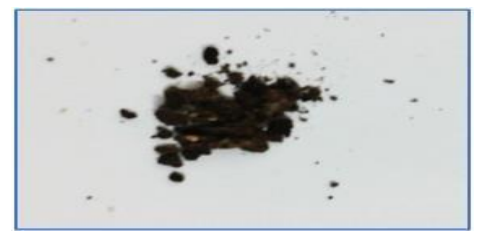

Gambar 8. Residu dengan Pelarut NaOH $4 \%$ dan $\mathrm{HCl} 3 \%$
Dari Gambar 8, terlihat bahwa residu berwarna cokelat kehitaman. Selain itu, berat residu kering yang dihasilkan sebesar $12,56 \%$ dengan tekstur sangat keras. Hal ini disebabkan karena akumulasi senyawa lignin yang terpisahkan dari selulosa.

Selanjutnya, residu yang dihasilkan dianalisis menggunakan FTIR untuk mengetahui gugus fungsi yang terkandung didalamnya. Hasil Spektrum analisis FTIR dan gugus fungsi yang dihasilkan diperlihatkan pada Gambar 9 dan Tabel 3.

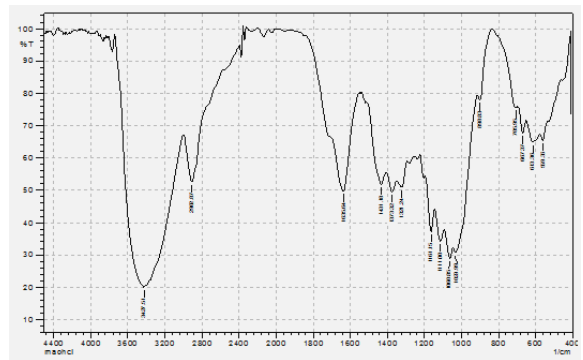

Gambar 9. Spektrum Analisis FTIR Residu dengan $\mathrm{NaOH} 4 \%$ dan $\mathrm{HCl} 3 \%$

Tabel 3. Gugus Fungsi Residu Variasi Pelarut NaOH 4\% dan HCl $3 \%$

\begin{tabular}{cccc}
\multicolumn{3}{c}{ Pelarut NaOH $\mathbf{4 \%}$ dan HCl 3\% } \\
\hline $\begin{array}{c}\text { Daerah Puncak } \\
\left(\mathbf{c m}^{-1}\right)\end{array}$ & Ikatan & Tipe Senyawa & Intensitas \\
\hline 3427,51 & $\mathrm{O}-\mathrm{H}$ & Fenol & Berubah-ubah \\
2902,87 & $\mathrm{C}-\mathrm{H}$ & Alkana & Kuat \\
1635,64 & $\mathrm{C}=\mathrm{C}$ & Alkena & Berubah-ubah \\
1431,18 & $\mathrm{C}-\mathrm{O}-\mathrm{C}$ & Aril-Alkil-Eter & Kuat \\
1321,24 & $\mathrm{NO}_{2}$ & Nitro & Kuat \\
$1060,86-1161,15$ & $\mathrm{C}-\mathrm{O}$ & Eter & Kuat \\
898,83 & $\mathrm{C}-\mathrm{H}$ & Cincin Aromatik & Kuat \\
706,96 & $\mathrm{C}-\mathrm{O}-\mathrm{C}$ & Aril-Alkil-Eter & Sangat Kuat \\
\hline
\end{tabular}

Berdasarkan Tabel 3, didapatkan adanya puncak pada $2902,87 \mathrm{~cm}^{-1}$ dan $3427,51 \mathrm{~cm}^{-1}$ yang menunjukkan peregangan ikatan $\mathrm{C}-\mathrm{H}$ dan $\mathrm{O}-\mathrm{H}$. Puncak-puncak tersebut timbul karena peregangan ikatan hidrogen dan pembengkokan dari grup hidroksil $(\mathrm{OH})$ pada struktur selulosa yang dihasilkan. Hasil analisis menunjukkan adanya daerah puncak pada $1431,18 \mathrm{~cm}^{-1}$ yang menunjukkan adanya gugus fungsi $\mathrm{C}$ $\mathrm{O}-\mathrm{C}$ (aril-alkil-eter) yang termasuk ke dalam gugus fungsi polimer lignin. Hal ini menunjukkan bahwa proses 
ekstraksi selulosa menggunakan variasi pelarut $\mathrm{NaOH} 4 \%$ dan $\mathrm{HC} 13 \%$ kurang efektif untuk menghilangkan lignin. Selain itu, terdapat daerah puncak $706,96 \mathrm{~cm}^{-1}$ (aril-alkil-eter) dengan intensitas sangat kuat. Hal ini menunjukkan adanya akumulasi senyawa lignin yang menyebabkan residu yang dihasilkan sangat keras dan berwarna cokelat kehitaman.

Persen berat selulosa dan lignin yang dihasilkan berdasarkan kepada hasil analisis HPLC diperlihatkan pada Gambar 10.

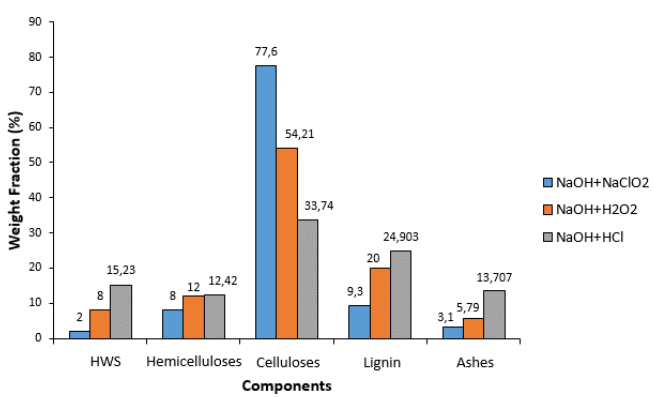

Gambar 10. Hasil Analisis HPLC

Gambar 10 memperlihatkan bahwa berat selulosa tertinggi dan berat ligin hemisesulosa terendah terjadi pada residu dengan variasi $\mathrm{NaOH} 4 \%$ dan $\mathrm{NaClO}_{2} 3 \%$. Terlihat pada Gambar 10 bahwa berat selulosa tertinggi sebesar $77,60 \%$. Sedangkan berat hemiselulosa dan ligin berturut turut sebesar $8 \%$ dan $9,3 \%$. Hal ini memperlihatkan bahwa selulosa berhasil diekstrak dan dipisahkan dari hemiselulosa dan lignin dengan baik. Dengan demikian $\mathrm{NaOH}$ $4 \%$ dan $\mathrm{NaClO}_{2} 3 \%$ merupakan pelarut yang efektif digunakan untuk memurnikan selulosa dengan melepaskan zat-zat pada batang eceng gondok dari selulosanya.

\section{SIMPULAN}

Jenis pelarut yang efektif untuk mengekstrak serat selulosa dari tanaman eceng gondok adalah pelarut $\mathrm{NaOH} 4 \%$ dan $\mathrm{NaClO}_{2} 3 \%$ dengan persen selulosa yang dapat diekstrak sebesar 77,60\%.

\section{DAFTAR RUJUKAN}

Ahmed, A. F., Moahmed A, Abdel Naby. (2012). Pretreatment and enzymic saccharification of water hyacinth cellulose. Carbohydrate Polymers.

Fengel,W.G(1995),Kayu, Universitas Gajahmada,Yogyakarta

Filho C and Ulrich H. 2012. Hydrogen Peroxide in Chemical Pulp Bleaching. Iberoamerican Congress on Pulp and Paper Research: Brasil

Greschik, T. (2008).Treatment of pulp.United State Application No.6.557.234 B1. 18 Mei 2006

Paulien dkk, 2010. Literature Review of Physical and Chemical Pretreatment Processes for Lignocellulosic Biomass. Wageningen UR Food and Biobased Research.

Rizky. D. H. (2012). Ekstraksi serat selulosa dari tanaman eceng gondok dengan variasi pelarut., Universitas Indonesia, Depok.

Sinaga,M.A (2008) Pengaruh Penambahan Hydrogen Peroksida Pada Stage Ekstraksi Terhadap Brightness Pulp, Universitas Sumatra Medan

Taherzadeh, M. J. a. K, K. (2007). AcidBased Hydrolysis Processes for Ethanol from Lignocellulosic Materials., A Review. Bioresources, 2(3), 472-499. 